\section{Hospitalizations during infancy in three population-based studies in Southern Brazil: trends and differentials}

\author{
Internações hospitalares durante a infância em três \\ estudos de base populacional no Sul do Brasil: \\ tendências e diferenciais
}

\author{
1 Programa de Pós-graduação \\ em Epidemiologia, \\ Universidade Federal de \\ Pelotas, Pelotas, Brasil. \\ 2 Departamento Materno- \\ Infantil, Universidad \\ Federal do Rio Grande, Rio \\ Grande, Brasil. \\ 3 Programa de Pós-graduação \\ em Saúde e Comportamento, \\ Universidade Católica de \\ Pelotas, Pelotas, Brasil. \\ Correspondence \\ A. Matijasevich \\ Programa de Pós-graduação \\ em Epidemiologia, \\ Universidade Federal \\ de Pelotas. \\ Rua Marechal Deodoro 1160, \\ 3 o andar, Pelotas, RS \\ 96020-220, Brasil. \\ amatija@yahoo.com
}

\section{Abstract}

Three cohort studies of children born in the urban area of Pelotas, Southern Brazil, were carried out in 1982, 1993, and 2004. The aim of these studies was to measure the occurrence of hospitalization in the first year of life and to examine the association between hospitalization and the cause of admission and sex, birth weight, and family income. Cause of admission was categorized as "diarrhea" and "all other causes". The frequency of children hospitalized at least once during their first year of life was 19.6\% in 1982, $18.1 \%$ in 1993, and $19.2 \%$ in 2004. There was a marked reduction in hospitalizations due to diarrhea, but the frequency of hospitalization for all causes remained constant. In all three cohorts, infants from poorer families and those born weighing under 2,000g showed the highest frequencies of hospitalization due to diarrhea and all other causes, and the latter also showed a marked increase in hospitalizations due to all causes. These findings could be explained by an epidemic of preterm births in the study population.

Hospitalization; Morbidity; Child Welfare; Cohort Studies

\author{
Alicia Matijasevich 1 \\ Juraci A. Cesar 1,2 \\ Iná S. Santos 1 \\ Aluísio J. D. Barros 1 \\ Maria Alice S. O. Dode 1 \\ Fernando C. Barros 3 \\ Cesar G. Victora 1
}

\section{Introduction}

Hospitalizations represent a significant expense for healthcare systems worldwide 1 . Moreover, the indirect costs of hospitalization, including absenteeism, unemployment, disability, and premature death, are also substantial 2,3. A number of studies demonstrate that among young people, children under age one year are at greatest risk of undergoing the most costly hospitalizations 1,4.

Respiratory infections are an important cause of hospitalization in children under five years of age 5,6. Worldwide, although the number of hospitalizations due to acute diarrhea has fallen with the advent of oral rehydration therapy 7 , these events continue to be preponderant in developing countries 8 . In Brazil, the foremost cause for hospitalization in children under one year in 2005 was respiratory infections, followed by diarrheic diseases 9 . However, in the country's Northeast Region in this same year, the proportion of admissions due to infectious and parasitic diseases was practically equal to that of diseases of the respiratory tract 9 .

Morbidity studies constitute an important complement to mortality data, describing the profile of diseases and contributing to the planning of hospital and outpatient services $10,11,12,13,14$. Health service records are important sources of data for studying disease, and can be used as an indicator of the health status of users 15 . However, data relating to hospital admis- 
sions are not always available, and often depend on specific studies. This was especially the case prior to theimplementation of computerized systems, such as the Brazilian Hospital Information System of the Unified National Health System (SIH-SUS; http://www.datasus.gov.br/catalogo/sihsus.htm), generated based on hospital admission authorizations issued through the SUS. Information on cause of admission are often incorrect, most often due to the lack of standardization of precise definitions for underlying causes of hospitalization, deficiencies in diagnosis, or - unfortunately - for financial reasons (illegal financial gain), either by the physician or the hospital 16,17.

In 1982, 1993, and 2004 18, three populationbased cohort studies were carried out in the city of Pelotas, Southern Brazil. Conditions at birth, growth, development and the occurrence of morbidity and death were assessed among children throughout their first year of life. These studies provide a unique opportunity for analyzing time trends with population-based samples. The present article is a follow-up to the study published by Cesar et al. 19, comparing hospitalization data of children from the 1982 and 1993 cohorts. The aim of the present article is to analyze trends and differentials in the occurrence and causes of hospitalization among infants, in an attempt to increase our understanding of the health-disease process in children over the last two decades.

\section{Methodology}

In 1982, 1993, and 2004, all births that took place in Pelotas were followed in cohort studies using a similar methodology 18 . The city's maternity wards were visited on a daily basis, and mothers were interviewed in the first hours after delivery. These interviews comprised questions on socioeconomic and demographic conditions, reproductive health, and health care during pregnancy and delivery.

At the beginning of 1983, we attempted to locate all children in the urban area born between January and April 1982, when they were approximately one year old. We were able to locate $79 \%$ of these children, with no important variation in the percentage of losses to follow-up according to family income 13 . During this interview, mothers provided information on whether or not their child had been hospitalized during that first year, and if so, on the cause of hospitalization, which was classified as due to either diarrhea or any other disease. Unfortunately, with the exception of diarrhea, the questionnaire used in this study did not allow us to extract detailed information on the cause of admission. We therefore considered as "hospitalized" any child who had stayed in the hospital for at least one night during their first year of life. A validation study comparing the responses of 120 mothers to hospital charts showed that the underlying cause of hospitalization had been correctly provided by the mother in $90 \%$ of cases 13 .

In 1993, a team was designated to measure the occurrence and determine the major causes for infant hospitalization in Pelotas. The city's five hospitals were visited on a daily basis in search of children born in 1993 who had been admitted to the hospital for a period equal to or greater than 24 hours. The mothers of these children were interviewed and hospital charts were reviewed and transcribed into standardized forms. Two independent researchers analyzed the above data and produced a report on the underlying cause of admission, based on the 9th International Classification of Diseases (ICD-9) 20. In the case of any disagreement, a third researcher was requested to give the final report. We were unable to obtain information for $1.7 \%$ of all hospitalizations that took place that year.

In 2004, we attempted to locate all children at the time of their first birthday; we were successful in $94 \%$ of cases. During this interview, mothers reported whether or not their children had been hospitalized during the first year, and the reason for hospitalization. We used the same definition of hospitalization employed for the 1993 cohort.

In order to compare the three cohorts, we studied the outcomes available for all three studies, that is, hospitalization due to diarrhea and all other causes. Independent variables included in the present report were sex, birth weight, and family income. In the three cohorts, newborns were weighed by maternity ward nurses immediately following delivery, using pediatric scales periodically calibrated by the research team 18 . Birth weight was analyzed in two ways: divided into five categories $(<2,000 \mathrm{~g}, 2,000-2,499 \mathrm{~g}, 2,500$ $2,999 \mathrm{~g}, 3,000-3,499 \mathrm{~g}$, and $\geq 3,500 \mathrm{~g}$ ), and as a binary variable $(<2,500 \mathrm{~g}$ or $\geq 2,500 \mathrm{~g})$.

Family income was measured in minimum wages earned in the month prior to birth, and was categorized into $\leq 1.0,1.1-3.0,3.1-6.0,6.1$ 10.0 , and $>10.0$ minimum wages.

We used the chi-squared test to measure the association between independent variables and the outcomes analyzed. Whenever possible, linear trend tests were used. All analyses were carried out using the Stata statistical package (Stata Corp., College Station, USA).

The study protocol was approved by the Medical Research Ethics Committee of the Federal University of Pelotas. In 1982 and 1993, verbal 
consent was obtained form mothers to participate in the study. In 2004, written consent was also requested.

\section{Results}

The frequency of children hospitalized at least once during the first year of life was $19.6 \%$ in $1982,18.1 \%$ in 1993 , and $19.2 \%$ in 2004 , remaining constant throughout the period ( $\mathrm{p}$ for linear trend $=0.7$ )

Table 1 shows that there were no statistically significant differences between hospitalization rates due to diarrhea between boys and girls in any of the cohorts. For all causes, the frequency of hospitalization was higher among boys, but this difference was significant only in 1982. In the two-decade period, there was a marked and significant reduction in hospitalization due to diar- rhea, but hospitalization rates due to all causes remained constant.

The percentage of hospitalizations due to diarrhea and all causes decreased markedly as income increased in all three cohorts (Table 2). Differentials for diarrhea were more marked than for all causes; this difference was more evident in 1982 than in the remaining cohorts. In 2004, no children with income higher than 6 minimum wages were hospitalized due to diarrhea. There was a surprising increase among the richest group in hospitalization due to all causes in the studied period.

Table 3 shows hospitalization due to diarrhea and all causes according to birth weight. In the three cohorts, children with lower birth weight were significantly more hospitalized due to diarrhea and all causes than other children. For each birth weight category, there was a decrease in the frequency of hospitalization due to

Table 1

Children hospitalized due to diarrhea and all causes during the first year of life, according to sex. Pelotas, Southern Brazil, 1982,1993, and 2004.

\begin{tabular}{|c|c|c|c|c|c|c|c|c|c|c|c|}
\hline \multirow[t]{2}{*}{ Sex } & \multicolumn{3}{|c|}{ Number of children } & \multicolumn{4}{|c|}{ Diarrhea (\%) } & \multicolumn{4}{|c|}{ All causes $(\%)$} \\
\hline & 1982 & 1993 & 2004 & $\begin{array}{c}1982 \\
(p=0.5 *)\end{array}$ & $\begin{array}{c}1993 \\
(p=0.9 *)\end{array}$ & $\begin{array}{c}2004 \\
\left(p=0.8^{*}\right)\end{array}$ & $p^{* *}$ & $\begin{array}{c}1982 \\
(p=0.01 *)\end{array}$ & $\begin{array}{c}1993 \\
(p=0.1 *)\end{array}$ & $\begin{array}{c}2004 \\
(p=0.2 *)\end{array}$ & $p^{* \star}$ \\
\hline Male & 714 & 671 & 2,024 & 6.5 & 3.3 & 1.0 & $<0.001$ & 21.9 & 19.6 & 19.9 & 0.3 \\
\hline Female & 743 & 693 & 1,883 & 6.1 & 3.1 & 0.9 & $<0.001$ & 17.4 & 16.7 & 18.3 & 0.5 \\
\hline Total & 1,457 & 1,364 & 3,907 & 6.3 & 3.2 & 1.0 & $<0.001$ & 19.6 & 18.1 & 19.2 & 0.7 \\
\hline
\end{tabular}

* $\chi^{2}$ for association between hospitalization and sex in each cohort;

** $\chi^{2}$ linear trend.

Children hospitalized due to diarrhea and all causes during the first year of life, according to family income. Pelotas, Southern Brazil, 1982,1993, and 2004.

\begin{tabular}{|c|c|c|c|c|c|c|c|c|c|c|c|}
\hline \multirow{3}{*}{$\begin{array}{l}\text { Family income } \\
\text { (as a multiple } \\
\text { of the monthly } \\
\text { minimum wage) }\end{array}$} & \multicolumn{3}{|c|}{ Number of children } & \multicolumn{4}{|c|}{ Diarrhea (\%) } & \multicolumn{4}{|c|}{ All causes $(\%)$} \\
\hline & 1982 & 1993 & 2004 & 1982 & 1993 & 2004 & $p$ ** & 1982 & 1993 & 2004 & $p$ ** \\
\hline & & & & \multicolumn{4}{|c|}{$(p=0.001 *)(p=0.03 *)(p=0.001 *)$} & \multicolumn{4}{|c|}{$(p=0.001 *)(p=0.001 *)(p=0.001 *)$} \\
\hline$\leq 1$ & 252 & 244 & 792 & 12.2 & 5.7 & 2.3 & $<0.001$ & 26.8 & 23.7 & 24.5 & 0.5 \\
\hline $1.1-3.0$ & 739 & 591 & 1,803 & 6.6 & 3.5 & 0.8 & $<0.001$ & 22.8 & 20.4 & 21.0 & 0.7 \\
\hline $3.1-6.0$ & 283 & 298 & 886 & 3.2 & 1.9 & 0.5 & $<0.001$ & 12.4 & 15.8 & 13.5 & 0.9 \\
\hline $6.1-10.0$ & 91 & 114 & 216 & 1.1 & 1.8 & 0.0 & - & 8.8 & 10.2 & 11.1 & 0.6 \\
\hline$>10$ & 85 & 93 & 199 & 1.2 & 0.0 & 0.0 & - & 3.5 & 7.5 & 12.6 & 0.01 \\
\hline Total & 1,450 & 1,340 & 3,896 & 6.3 & 3.2 & 1.0 & $<0.001$ & 19.6 & 18.1 & 19.2 & 0.7 \\
\hline
\end{tabular}

* $\chi^{2}$ for association between hospitalization and family income in each cohort;

${ }^{\star *} \chi^{2}$ linear trend. 
Children hospitalized due to diarrhea and all causes during the first year of life, according to birth weight. Pelotas, Southern Brazil, 1982,1993, and 2004.

\begin{tabular}{|c|c|c|c|c|c|c|c|c|c|c|c|}
\hline \multirow{3}{*}{$\begin{array}{l}\text { Birth } \\
\text { weight } \\
\text { (g) }\end{array}$} & \multicolumn{3}{|c|}{ Number of children } & \multicolumn{4}{|c|}{ Diarrhea (\%) } & \multicolumn{4}{|c|}{ All causes (\%) } \\
\hline & 1982 & 1993 & 2004 & 1982 & 1993 & 2004 & $p$ ** & 1982 & 1993 & 2004 & $p$ ** \\
\hline & & & & \multicolumn{4}{|c|}{$(p=0.001 *)(p=0.007 *)(p=0.001 *)$} & \multicolumn{4}{|c|}{$\left(p=0.001^{\star}\right)(p=0.001 *)(p=0.001 *)$} \\
\hline$<2,000$ & 22 & 79 & 97 & 31.8 & 3.7 & 2.1 & & 40.9 & 71.6 & 73.2 & \\
\hline $2,000-2,499$ & 78 & 317 & 248 & 9.0 & 6.1 & 1.6 & & 34.6 & 35.9 & 32.3 & \\
\hline $2,500-2,999$ & 343 & 253 & 973 & 5.5 & 4.0 & 1.9 & & 20.6 & 18.2 & 21.7 & \\
\hline $3,000-3,499$ & 566 & 432 & 1,549 & 5.8 & 3.0 & 0.5 & & 18.0 & 13.6 & 16.0 & \\
\hline$\geq 3,500$ & 447 & 270 & 1,039 & 5.8 & 1.8 & 0.6 & & 17.2 & 14.6 & 13.4 & \\
\hline Total & 1,456 & 1,351 & 3,906 & 6.3 & 3.2 & 1.0 & $<0.001$ & 19.6 & 18.1 & 19.2 & 0.7 \\
\hline
\end{tabular}

* $\chi^{2}$ for association between hospitalization and birth weight in each cohort;

${ }^{\star *} \chi^{2}$ linear trend.

diarrhea during the period. In the 1982 cohort, hospitalization due to diarrhea among children weighing under $2,000 \mathrm{~g}$ was three to five times higher than among other weight groups. In 1993 and 2004, on the other hand, differences in the frequency of hospitalization between the different birth weight groups were much smaller. Although hospitalizations due to all causes increased among children under 2,000g, hospitalizations due to all causes remained constant throughout the period for the remaining birth weight categories.

Figure 1 shows the occurrence of hospitalizations due to all causes according to family income and birth weight in the three cohorts. In all three studies, children from families earning three times the monthly minimum wage or less were twice as likely to be hospitalized than children with higher incomes $\left(\chi^{2} \mathrm{p}<0.001\right.$ in 1982, 1993, and 2004). Children born weighing less than 2,500g stood roughly double the likelihood of being hospitalized in 1982 than in 1993 $\left(\chi^{2} \mathrm{p}<0.001\right)$. In the 2004 cohort, there was an increase in hospitalizations among this group of children, surpassing the frequencies observed in $1993\left(\chi^{2} \mathrm{p}<0.001\right)$. The difference between 1982 and 2004 was not significant $\left(\chi^{2} p=0.2\right)$. For children weighing $2,500 \mathrm{~g}$ or more, the hospitalization frequency fell between 1982 and $1993\left(\chi^{2}\right.$ $\mathrm{p}<0.001)$, and remained stable between 1993 and $2004\left(\chi^{2} \mathrm{p}=0.5\right)$.

\section{Discussion}

Certain methodological differences between the three cohorts should be considered. Although the
1993 and 2004 studies defined hospitalization as the permanence of the child in the hospital for at least 24 hours, in 1982 an overnight stay was sufficient for a child to be considered hospitalized. This difference may have led to an overestimation of hospitalization rates in 1982 in relation to the other cohorts due to the differences in case definition. It should be noted, however, that the percentage of hospitalizations due to all causes remained virtually stable - at around $20 \%$ - in all three cohorts.

In the period under study, important changes took place in the profiles of infant morbidity and mortality. At the global level, in the 1980s diarrhea was the foremost cause of death, accounting for over 4 million infant deaths yearly 21 . Despite the decrease in the number of deaths to 1.5 million in 2000, diarrhea is still one of the main causes of under-five mortality and morbidity worldwide 21 .

As in other countries 22, infant mortality due do diarrhea has fallen in Brazil 7,23. Much of this reduction is attributed to the widespread use of oral rehydration therapy, which made diarrhea treatable within the household and at the primary healthcare level 24,25 . The decrease in frequency of diarrhea among the infant population has been documented in different Brazilian regions 26,27 . Increases in family purchasing power, expanded coverage of public water supply services, and increases in the median breastfeeding duration 28 , have, among other factors, contributed to the reduction observed in diarrhea mortality.

Even though diarrhea is in certain countries no longer considered as a major threat to infant survival, the cost of hospitalizations due to diar- 


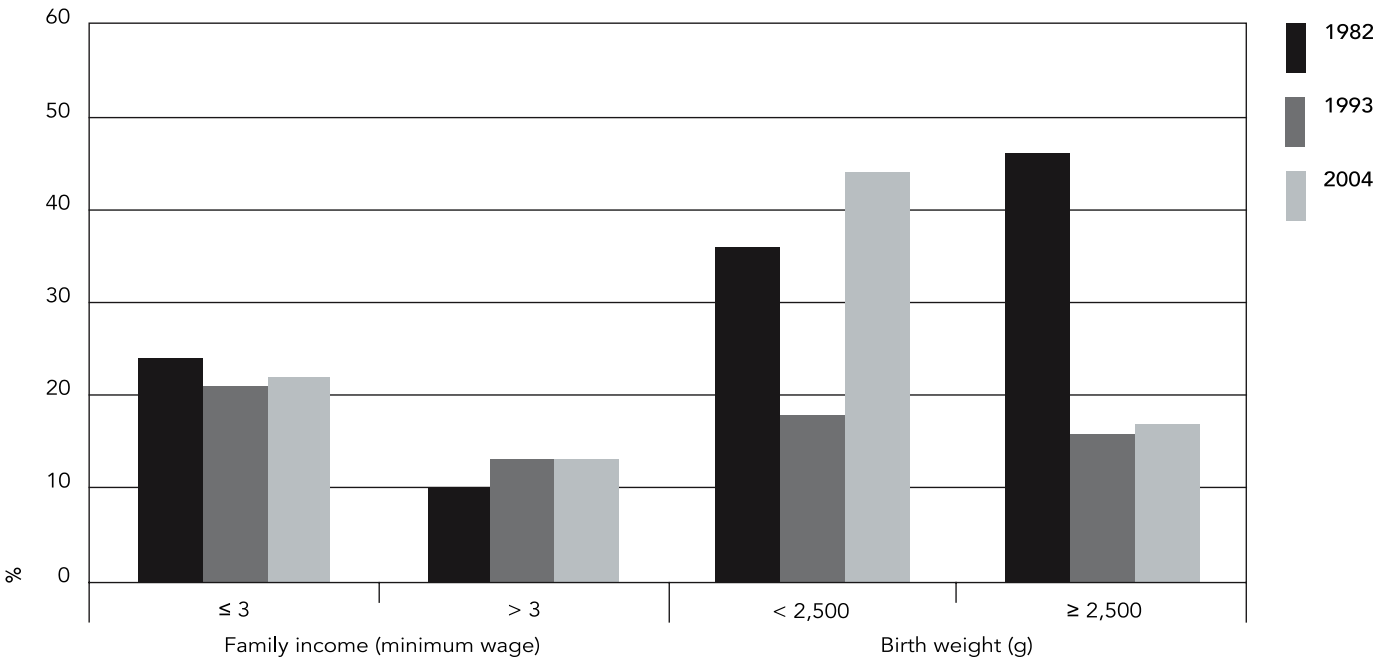

rhea are important from the public health perspective 29,30 . The present study shows a drastic reduction in the frequency of diarrhea-related hospitalizations in the period. A similar reduction was also documented by another research group in the city of São Paulo, Brazil 31. It is likely that the same factors that contributed to the reduction in mortality also reduced the frequency of hospitalization, especially improvements in outpatient management of diarrhea through oral rehydration therapy.

Results regarding the socioeconomic differentials in hospitalization are extremely interesting. Berkson's paradox 32 - poor children being hospitalized more frequently than rich children with equally severe episodes - may explain part of the differentials presented here. Notwithstanding, diarrhea is shown to be a disease that is typical of poor children, this trend being stronger in the first cohort, when the differences between income groups were greater 13 . To date, poor sanitation and living conditions and low levels of maternal schooling, among other factors, continue to be the major determinants of diarrhea at the global level 31,33,34,35.

As demonstrated by other studies, children with lower birth weight were significantly less hospitalized both due to diarrhea as well as to all causes combined 13,35. In terms of diarrhearelated hospitalizations, the greatest difference between children weighing under 2,000g and the remainder was found in 1982. In that year, in addition to diarrhea being more prevalent than in the later cohorts, the use of oral rehydration therapy at the household level was uncommon, and therefore dehydration was much more frequent and severe, thus increasing the number of hospitalizations due to diarrhea.

There was a marked increase in hospitalization due to all causes in the group of children weighing under $2,000 \mathrm{~g}$. This is probably related to the increase in preterm births in the 2004 and - to a lesser extent -1993 cohorts 36 .

In summary, two factors were strongly associated with higher rates of hospitalization among the city's children: family income and birth weight. Children from poorer families and with lower birth weight were hospitalized more frequently during the first year of life. These findings were consistent throughout the 22 years covered by the three studies. Family income is a complex phenomenon, whose modification does not depend directly on the actions of healthcare professionals. On the other hand, a reduction in the number of preterm births, which is directly linked to the quality of medical care, could markedly contribute to reducing hospitalizations and to avoiding the negative consequences of hospitalizations for children and their families. 


\section{Resumo}

Foram organizadas três coortes de crianças nascidas na área urbana de Pelotas, Rio Grande do Sul, em 1982, 1993 e 2004. O presente estudo teve como objetivos medir a ocorrência de hospitalização no primeiro ano de vida e estudar a associação entre hospitalização e causa de internação e sexo, peso ao nascer e renda familiar. As causas de internação eram categorizadas como "diarréia" e "todas as outras causas". As proporções de crianças hospitalizadas pelo menos uma vez durante o primeiro de ano de vida foram 19,6\% em 1982, 18,1\% em 1993 e 19,2\% em 2004. Houve uma redução marcante nas internações por diarréia, enquanto permanecia constante a freqüência de internações por todas as causas. Nas três coortes, as crianças de famílias mais pobres e aquelas que nasceram com peso abaixo de $2000 \mathrm{~g}$ mostraram as freqüências mais elevadas de internações por diarréia e por todas as outras causas, $e$ a coorte de 2004 também mostrou um aumento marcante nas internações por todas as causas. Os achados podem ser explicados por uma epidemia de nascimentos prematuros na população estudada.

Hospitalização; Morbidade; Bem-Estar da Criança; Estudos de Coortes

\section{References}

1. Merrill CT, Elixhauser A. Hospitalization in the United States, 2002: HCUP Fact Book No. 6. AHRQ Publication no. 05-0056. http://www.ahrq.gov/data/hcup/factbk6/ (accessed on 30/Aug/2007).

2. Levesque JF, Haddad S, Narayana D, Fournier P. Affording what's free and paying for choice: comparing the cost of public and private hospitalizations in urban Kerala. Int J Health Plann Manage 2007; 22:159-74.

3. Weiss KB, Sullivan SD, Lyttle CS. Trends in the cost of illness for asthma in the United States, 19851994. J Allergy Clin Immunol 2000; 106:493-9.

4. Ku L. Who is paying the big bills? Very high cost pediatric hospitalizations in California, 1987. U.S. Department of Health and Human Services. http://aspe.hhs.gov/daltcp/reports/bigblles.htm (accessed on 30/Aug/2007)

5. Caetano JR, Bordin IA, Puccini RF, Peres CA. Fatores associados à internação hospitalar de crianças menores de cinco anos, São Paulo, SP. Rev Saúde Pública 2002; 36:285-91.

6. Carville SK, Lehmann D, Hall G, Moore H, Richmond P, de Klerk N, et al. Infection is the major component of disease burden in aboriginal and non-aboriginal Australian children: a populationbased study. Pediatr Infect Dis J 2007; 26:210-6.

\section{Contributors}

A. Matijasevich drew up the research question, conducted the analyses and wrote the first draft of the article. C. G. Victora drew up the research question, supervised the analysis and interpretation of the findings as well as the writing of the article. J. A. Cesar, I. S. Santos, A. J. D. Barros, and F. C. Barros contributed to the interpretation of the analyses and assisted with the editing of the article. M. A. S. O. Dode contributed to data collection and to the interpretation of the findings.
7. Victora CG, Olinto MT, Barros FC, Nobre LC. Falling diarrhoea mortality in Northeastern Brazil: did ORT play a role? Health Policy Plan 1996; 11: $132-41$.

8. World Health Organization. The world health report. Geneva: World Health Organization; 1999.

9. Ministério da Saúde. Indicadores de morbidade e fatores de risco. D13. Proporção de internações hospitalares (SUS) por grupos de causas, 2005. http://tabnet.datasus.gov.br/cgi/tabcgi.exe? idb2006/d13.def (accessed on 04/Sep/2007).

10. Ross DA, Vaughan JP. Health interview surveys in developing countries. London: Evaluation and Planning Centre for Health Care; 1984.

11. Rouquayrol MZ. Epidemiologia e saúde. 4a Ed. Rio de Janeiro: Editora Medsi; 1994.

12. Lima M. Epidemiologia: teoria e prática. Rio de Janeiro: Editora Guanabara Koogan; 1995.

13. Victora CG, Barros FC, Vaughan JP. Epidemiologia da Desigualdade: um estudo longitudinal de 6.000 crianças brasileiras. 2a Ed. São Paulo: Editora Hucitec; 1988.

14. Costa JS. Utilização de serviços ambulatoriais em Pelotas [Dissertação de Mestrado]. Pelotas: Faculdade de Medicina, Universidade Federal de Pelotas; 1993. 
15. Laurenti R. A medida das doenças. In: Forattini OP, organizador. Epidemiologia geral. São Paulo: Artes Médicas; 1987. p. 64-91.

16. Veras CMT, Martins MS. A confiabilidade dos dados nos formulários de Autorização de Internação Hospitalar (AIH), Rio de Janeiro, Brasil. Cad Saúde Pública 1994; 10:339-55.

17. Barros MB. Morbidade e mortalidade hospitalar de crianças menores de um ano, em Ribeirão Preto, SP (Brasil), 1975. Rev Saúde Pública 1981; 15: 308-20.

18. Barros AJD, Santos IS, Matijasevich A, Araújo CL, Gigante DP, Menezes AMB, et al. Methods used in the 1982, 1993, and 2004 birth cohort studies from Pelotas, Rio Grande do Sul State, Brazil, and a description of the socioeconomic conditions of participants' families. Cad Saúde Pública 2008; 24 Suppl 3:S371-80.

19. Cesar JA, Victora CG, Barros FC, Ramos FA, Albernaz EP, Oliveira LM. Hospitalizações em menores de um ano pertencentes a duas coortes de base populacional no Sul do Brasil: tendências e diferenciais. Cad Saúde Pública 1996; 12 Suppl 1: S67-71.

20. World Health Organization. International statistical classification of diseases and related health problems. Ninth revision. Geneva: World Health Organization; 1982.

21. Bern C, Martines J, Zoysa I, Glass RI. The magnitude of the global problem of diarrhoeal disease: a ten-year update. Bull World Health Organ 1992; 70:705-14

22. Kilgore PE, Holman RC, Clarke MJ, Glass RI. Trends of diarrheal disease--associated mortality in US children, 1968 through 1991. JAMA 1995; 274:1143-8.

23. Monteiro CA, Nazário CL. Declínio da mortalidade infantil equidade social; o caso da cidade de São Paulo entre 1973 e 1993. In: Monteiro CA, editor. Velhos e novos males da saúde no Brasil: a evolução do país e de suas doenças. São Paulo: Editora Hucitec/Universidade de São Paulo; 1995. p. 173-85.

24. Campos GJ, Reis Filho SA, Silva AA, Novochadlo MA, Silva RA, Galvao CE. Infant morbimortality due to acute diarrhea in a metropolitan área of northeastern Brazil, 1986-1989. Rev Sáude Pública 1995; 29:132-9.

25. Victora CG, Bryce J, Fontaine O, Monasch R. Reducing deaths from diarrhoea through oral rehydration therapy. Bull World Health Organ 2000; 78:1246-55.
26. Sastry N, Burgard S. The prevalence of diarrheal disease among Brazilian children: trends and differentials from 1986 to 1996. Soc Sci Med 2005; 60:923-35.

27. Benicio MH, Monteiro CA. Secular trends in diarrhea disease of childhood in the city of São Paulo, Brazil (1984-1996). Rev Saúde Pública 2000; 34(6 Suppl):83-90.

28. Victora CG, Matijasevich A, Santos IS, Barros AJD, Horta BL, Barros FC. Breastfeeding and feeding patterns in three birth cohorts in Southern Brazil: trends and differentials. Cad Saúde Pública 2008; 24 Suppl 3:S409-16.

29. Glass RI, Lew JF, Gangarosa RE, LeBaron CW, Ho MS. Estimates of morbidity and mortality rates for diarrheal diseases in American children. J Pediatr 1991; 118(4 Pt 2):S27-33.

30. Jin S, Kilgore PE, Holman RC, Clarke MJ, Gangarosa EJ, Glass RI. Trends in hospitalizations for diarrhea in United States children from 1979 through 1992: estimates of the morbidity associated with rotavirus. Pediatr Infect Dis J 1996; 15:397-404.

31. Genser B, Strina A, Teles CA, Prado MS, Barreto ML. Risk factors for childhood diarrhea incidence: dynamic analysis of a longitudinal study. Epidemiology 2006; 17:658-67.

32. Berkson J. Limitations of the applications of fourfold table analysis to hospital data. Biometrics 1946; 2:47-53.

33. Ethelberg S, Olesen B, Neimann J, Schiellerup P, Helms M, Jensen C, et al. Risk factors for diarrhea among children in an industrialized country. Epidemiology 2006; 17:24-30.

34. Checkley W, Gilman RH, Black RE, Epstein LD, Cabrera L, Sterling CR, et al. Effect of water and sanitation on childhood health in a poor Peruvian peri-urban community. Lancet 2004; 363:112-8.

35. Parashar UD, Kilgore PE, Holman RC, Clarke MJ, Bresee JS, Glass RI. Diarrheal mortality in US infants. Influence of birth weight on risk factors for death. Arch Pediatr Adolesc Med 1998; 152:47-51.

36. Barros FC, Victora CG, Matijasevich A, Santos IS, Horta BL, Silveira MF, et al. Preterm births, low birth weight, and intrauterine growth restriction in three birth cohorts in southern Brazil. 1982, 1993 and 2004. Cad Saúde Pública 2008; 24 Suppl 3: S390-8.

Submitted on 29/Mar/2007

Final version resubmitted on $07 /$ Nov/2007

Approved on 10/Jan/2008 